DOI: http://dx.doi.org/10.33846/hn40704

http://heanoti.com/index.php/hn

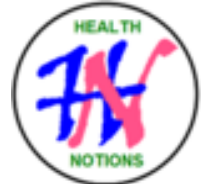

RESEARCH ARTICLE

URL of this article: http://heanoti.com/index.php/hn/article/view/hn40704

\title{
Effects of Classical Music, Natural and Murottal Music on Fetal Well-Being
}

\author{
Rahayu Sumaningsih" ${ }^{1(\mathrm{CA})}$, Teta Puji Rahayu², Budi Joko Santosa ${ }^{3(\mathrm{CA})}$ \\ ${ }^{1}$ Poltekkes Kemenkes Surabaya of Ministry of Health, Indonesia; rahayusumaningsih@yahoo.com \\ ${ }^{2}$ Poltekkes Kemenkes Surabaya of Ministry of Health, Indonesia; tetapujirahayu@gmail.com \\ ${ }^{3(\mathrm{CA})}$ Poltekkes Kemenkes Surabaya of Ministry of Health, Indonesia; santosabudijoko@yahoo.co.id \\ (Corresponding Author)
}

\begin{abstract}
Music affects to human psychology, provides a sense of security, comfort and fun. Classical, natural and murottal music has a tone, rhythm, speed, gentle meter capable of stimulating alpha waves, calmness, and relaxation, beneficial to the well-being of the fetus. The purpose of this study is to describe classical, natural and murotal music on fetal well-being. This Quasi-Experiment Research with pretest-posttest design. A sample of 40 individuals was divided into 4 groups of mothers. The independent variable is classical music, natural, murotal and without music. The dependent variable is fetal well-being. The mean values before and after the intervention naturally were calculated. The results of fetal well-being based on the fetal heart rate of the classical music group before treatment there were $10 \%$ of fetuses experiencing mild aspysia after treatment of the fetus experiencing 0\% aspysia. Natural and Murottal Music Group before and after treatment 100\% normal fetal heart rate, group without music, before and after treatment $50 \%$ of fetuses experience Mild Aspysia. Fetal wellbeing results are based on Apgar Score, the Classical Music group after listening to classical music $10 \%$ experienced mild Aspysia. Natural Music Group and Murottal after listening to natural music and murottal $100 \%$ of babies under normal circumstances. The group without music after birth $50 \%$ of babies experience mild Aspysia. Conclusion, classical music overcomes mild asphyxia based on fetal heart rate, natural and murrotal music effectively maintains fetal well-being until birth.

Keywords: classical music; natural music; murottal; fetal well-being
\end{abstract}

\section{INTRODUCTION}

\section{Background}

Music was created to influence the condition of human psychology, especially in maternal physical and psychological problems that occur even a lot of social. Physical problems that occur due to pain due to uterine contractions and decrease in the bottom of the fetus. Psychological problems are anxiety, fear of childbirth while social problems are afraid of losing the fetus and solitude, so the need for assistance with health workers and family $^{(1)}$.

The impact of music therapy interventions can change the threshold of the brain in a stressful state to be more physiologically and effectively adaptive. Music does not require the brain to think or interpret, nor is it then limited by intellectual functions or mental thoughts so that it is easily accepted by the hearing organ ${ }^{(2-4)}$.

Listening to music can have a very relaxing effect on the mind and body, especially slow music, like quiet classical music. This type of music can have beneficial effects on physiological functions, slowing the pulse and heart rate, lowering blood pressure, and reducing levels of stress hormones ${ }^{(5)}$.

\section{METHODS}

This research was a quasi-pretest-posttest with control group experiment. The population of pregnant women in Magetan district, a sample of 40 individuals in multi-stage. Data collection measures fetal heart rate 
and APGAR score of newborns. Data entry was processed descriptively in percentage and mean, interpreted in $100 \%$ standard. This study naturally gave treatment to 3 intervention groups and 1 control group. Three groups were given music therapy intervention for about 30 minutes, classical music, natural music, murottal, without music. The four previous music groups measured the mother's vital signs and fetal well-being were then treated with music therapy 1 time for 30 minutes then the mother's vital signs and fetal well-being were measured (post treatment) and after delivery the fetal welfare was measured through the APGAR score ${ }^{(2)}$.

\section{RESULTS}

\section{Vital Sign Before dan After Intervention}

Table 1. Distribution of mean vital sign, before and after intervention

\begin{tabular}{lcccccc}
\hline \multirow{2}{*}{ Group } & & $\begin{array}{c}\text { Blood } \\
\text { pressure }\end{array}$ & Pulse & Temperature & Breath & $\begin{array}{c}\text { Fetal heart } \\
\text { rate }\end{array}$ \\
& & & & & & \\
\hline \multicolumn{2}{c}{ Classical music: Before } & 114 & 83.4 & 36.7 & 20.6 & 140.3 \\
& After & 112 & 82.2 & 36.7 & 19.8 & 141.4 \\
Natural music: & Before & 127.9 & 87.6 & 36.6 & 21.0 & 146.8 \\
& After & 117.9 & 82.2 & 36.5 & 18.6 & 136.8 \\
Murottal: & Before & 119.0 & 81.8 & 36.7 & 21.6 & 139.4 \\
& After & 116.0 & 80.2 & 36.6 & 20.8 & 138.4 \\
Without music: & Before & 108.0 & 79.8 & 36.7 & 20.2 & 111.6 \\
& After & 108.0 & 80.1 & 36.7 & 18.3 & 111.2 \\
\hline
\end{tabular}

Table 2. Fetal well-being is based on fetal heart rate before and after intervention

\begin{tabular}{lccc}
\hline \multirow{2}{*}{ Group } & \multicolumn{2}{c}{ Fetal heart rate } \\
\cline { 2 - 3 } & & Normal & Mild asphyxia \\
\hline Classical music: Before & $9(90 \%)$ & $1(10 \%)$ \\
After & $10(100 \%)$ & $0(0 \%)$ \\
Natural music: & Before & $10(100 \%)$ & $0(0 \%)$ \\
Murottal: & After & $10(100 \%)$ & $0(0 \%)$ \\
& Before & $10(100 \%)$ & $0(0 \%)$ \\
Aithout music: & Before & $10(100 \%)$ & $0(0 \%)$ \\
& After & $0(0 \%)$ & $10(100 \%)$ \\
& & $0(100 \%)$ & $10 \%$ \\
\hline
\end{tabular}


Table 3. Fetal well-being is based on APGAR score before and after intervention

\begin{tabular}{lccc}
\hline \multirow{2}{*}{ Group } & \multicolumn{2}{c}{ Fetal heart rate } \\
\cline { 2 - 4 } & Normal & Mild asphyxia \\
\hline Classical music: After & $9(90 \%)$ & $1(10 \%)$ \\
Natural music: & After & $10(100 \%)$ & $0(0 \%)$ \\
Murottal: & After & $10(100 \%)$ & $0(0 \%)$ \\
Without music: & After & $5(50 \%)$ & $5(50 \%)$ \\
\hline
\end{tabular}

\section{DISCUSSION}

On were given music intervention, the vital signs of the pre and post test groups of classical music, natural music, Murottal, generally decreased, the group without music is relatively the same, the natural music group experienced the sharpest decline, the fetal heart rate did not have significant differences $(p>0.05)$ with a $\mathrm{p}$ value of $0.938^{(2)}$. The natural music group in the pre and post test all had significant differences in the reduction in vital signs and fetal heart rate because the value was less than $p<0.05$, so was the case in the Murottal group ${ }^{(2)}$.

Based on the result intervention in the Classical Music group, it was found that Pre as many as 9 people with normal fetal heart rate, $1(10 \%)$ had mild aspysia, but after the intervention, all respondents became normal. Natural and Murottal Music Group both in Pre and Post Treatment of fetal heart rate under normal conditions, in the Without music group without Pre and Post treatment there were 10 people experiencing Mild Aspysia, because the average results were 111 times per minute while the normal value was between 120-160 times per minutes, then the mother is advised to tilt to the left if necessary given oxygen ${ }^{(6)}$.

Also we get the Apgar score in the Classical Music Group: 9 people 90\% obtained normal Apgar score, 1 person 10\% experienced mild Aspysia. Natural Music Group: Apgar score of 10 people 100\% of babies in normal condition. Murottal group: found 7 people $70 \%$ Apgar score is normal, 3 people $30 \%$ have mild Aspysia. Without music group: obtained as many as 5 people 50\% Apgar Score under normal circumstances, 5 people 50\% experienced mild Aspysia. Management of mild aspysia does not need special cough only given "HAIKAP" (Warm Position Adjustment, Mucus Suction, Dry and Assessment) so that the baby cries strong and moves actively ${ }^{(3)}$.

\section{CONCLUSION}

Listening to classical, natural and murrotal music is effective for improving fetal well-being. This type of natural music is the most effective way to improve fetal well-being compared to other types. It is recommended to listen to music more focused through headphones and further research with a varied culture.

\section{REFERENCES}

1. Sumaningsih R, Santosa BJ. The effect of music relaxation and hypnobirthing on pain and duration of normal labor (Pengaruh relaksasi musik dan hypnobirthing terhadap rasa nyeri dan lama kala I persalinan normal). Jurnal Penelitian Kesehatan Suara Forikes. 2014;116-119.

2. Arikunto S. Research procedure: A practical approach (Prosedur penelitian: Suatu pendekatan praktik). Jakarta: PT Asdi Mahasatya; 2013.

3. Kind Health. APGAR score [Internet]. Kind Health. 2017 [cited 2018 Oct 16]. Available from: https://kidshealth.org/en/parents/apgarskor.html.

4. Djohan. Music therapy: Theory and applications (Terapi musik: Teori dan aplikasi). Jakarta: Galang Press; 2006.

5. Sumaningsih R, Santosa BJ. The difference in the response to pain and the length of the first period of labor with the administration of classical music, mozart and modern kitaro instruments (Perbedaan respon nyeri dan lama kala I bersalin dengan pemberian musik klasik, mozart dan instrumen modern kitaro). Jurnal 
Penelitian Kesehatan Suara Forikes. 2017; 9(2):45.

6. Chuthshall. Effect of the combination of music and nature sound on pain and anxiety in cardilac surgical Saint Marys Hospital [Internet]. Mayoclinic. 2011 [cited 2018 May14]. Available from: https://mayoclinic.pure.elsevier.com 